University of Wollongong

Research Online

January 2020

Beyond static spatial management: Scientific and legal considerations for dynamic management in the high seas

Guillermo Ortuno Crespo

Joanna Mossop

Daniel Dunn

Kristina Gjerde

Elliott Hazen

See next page for additional authors

Follow this and additional works at: https://ro.uow.edu.au/balpapers

Research Online is the open access institutional repository for the University of Wollongong. For further information contact the UOW Library: research-pubs@uow.edu.au 


\title{
Beyond static spatial management: Scientific and legal considerations for dynamic management in the high seas
}

\author{
Abstract \\ Natural and human stressors in the high seas act across a wide range of spatial and temporal scales. \\ These include direct interaction such as fisheries bycatch or indirect interaction like warming oceans and \\ plastic ingestion. Area-based management tools (ABMTs), such as marine protected areas and time-area \\ closures, are a widely accepted and a broadly successful form of management used to mitigate localized \\ human impacts on marine species and ecosystems. Protection provides an opportunity for population \\ recovery, which can then propagate outside of the closure. As the United Nations negotiates a new treaty \\ on the conservation and sustainable use of biodiversity beyond national jurisdiction, efforts to design and \\ implement high seas ABMTs at appropriate scales are critical to ensure that these spatial protection \\ measures are most effective and climate-ready in the face of changing oceans. Here we identify the four \\ most important temporal scales - contemporary, intra-annual, multi-annual and multidecadal - for aligning \\ high seas ABMTs to relevant ecological, oceanographic and atmospheric processes. From this, we \\ explore how managers and decision-makers can integrate this knowledge when implementing a new \\ treaty.

\section{Publication Details} \\ G. Ortuno Crespo, J. Mossop, D. Dunn, K. Gjerde, E. Hazen, G. Reygondeau, R. Warner, D. Tittensor \& P. \\ Halpin, 'Beyond static spatial management: Scientific and legal considerations for dynamic management \\ in the high seas' (2020) Marine Policy \\ Authors \\ Guillermo Ortuno Crespo, Joanna Mossop, Daniel Dunn, Kristina Gjerde, Elliott Hazen, Gabriel \\ Reygondeau, Robin M. Warner, Derek Tittensor, and Patrick Halpin
}




\title{
Beyond static spatial management: Scientific and legal considerations for dynamic management in the high seas
}

\author{
Guillermo Ortuño Crespo ${ }^{\mathrm{a}, *}$, Joanna Mossop ${ }^{\mathrm{b}}$, Daniel Dunn ${ }^{\mathrm{c}}$, Kristina Gjerde ${ }^{\mathrm{i}}$, Elliott Hazen ${ }^{\mathrm{d}}$, \\ Gabriel Reygondeau ${ }^{\mathrm{e}, \mathrm{g}}$, Robin Warner ${ }^{\mathrm{f}}$, Derek Tittensor ${ }^{\mathrm{h}}$, Patrick Halpin ${ }^{\mathrm{a}}$ \\ ${ }^{\text {a }}$ Duke University, USA \\ ${ }^{\mathrm{b}}$ Victoria University of Wellington, New Zealand \\ ${ }^{\mathrm{c}}$ University of Queensland, Australia \\ ${ }^{\mathrm{d}}$ National Oceanic and Atmospheric Administration (NOAA), USA \\ e University of British Columbia, Canada \\ ${ }^{\mathrm{f}}$ University of Wollongong, Australia \\ ${ }^{g}$ Yale University, USA

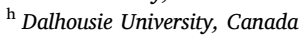 \\ ${ }^{\mathrm{i}}$ International Union for Conservation of Nature (IUCN), Switzerland
}

\section{A B S T R A C T}

Natural and human stressors in the high seas act across a wide range of spatial and temporal scales. These include direct interaction such as fisheries bycatch or indirect interaction like warming oceans and plastic ingestion. Area-based management tools (ABMTs), such as marine protected areas and time-area closures, are a widely accepted and a broadly successful form of management used to mitigate localized human impacts on marine species and ecosystems. Protection provides an opportunity for population recovery, which can then propagate outside of the closure. As the United Nations negotiates a new treaty on the conservation and sustainable use of biodiversity beyond national jurisdiction, efforts to design and implement high seas ABMTs at appropriate scales are critical to ensure that these spatial protection measures are most effective and climate-ready in the face of changing oceans. Here we identify the four most important temporal scales contemporary, intra-annual, multi-annual and multidecadal - for aligning high seas ABMTs to relevant ecological, oceanographic and atmospheric processes. From this, we explore how managers and decision-makers can integrate this knowledge when implementing a new treaty.

\section{Introduction}

Biodiversity in marine areas beyond national jurisdiction (ABNJ) is at a disproportionately higher mismanagement risk and legal vulnerability compared to biodiversity within the exclusive economic zones (EEZs) [1]. ABNJ contains $90 \%$ of the total biomass of the global ocean [2], so as human activities continue to spread further and deeper into the ocean [3], it is critical that marine conservation and management mechanisms evolve to abate cumulative impacts across ecological, spatial and temporal scales. This expansion poses a significant challenge to management authorities in ABNJ, where complex dynamics, a limited understanding of the ecological impacts of human activities and a widespread deficiency of monitoring, control and enforcement mechanisms, severely restrict conservation and sustainable management efforts [4-6]. While multiple international instruments and agreements call for a precautionary approach to the management of ocean resources and ecosystems (see International Tribunal for the Law of the Sea
(ITLOS) Advisory Opinion at paragraphs 131-135 and UN Fish Stocks Agreement, Article 6), there are few examples of impact avoidance in the open-ocean (e.g. though the use of spatial management measures) and most impact reduction efforts in the pelagic environment are focused on mitigation (e.g. changes in fishing gear to reduce bycatch rates), which diminish the risk instead of eliminating it. Impact avoidance and mitigation efforts are complementary and should be used in tandem, especially avoidance measures that reduce the chance of spatial and temporal overlap between stressors and vulnerable species or ecosystems.

While the scale of today's human activities and impacts in the marine realm have grown massively since UNCLOS was drafted, the institutional arrangements to manage negative ecological impacts, particularly on biodiversity beyond national jurisdiction (BBNJ), have not kept pace. A fragmented patchwork of sectoral management bodies in the ABNJ impedes the harmonization of responses to sectoral and cross-sectoral cumulative impacts [4]. The ongoing Intergovernmental Conference

\footnotetext{
* Corresponding author.

E-mail address: gortunocrespo@gmail.com (G. Ortuño Crespo).
} 
(IGC) to negotiate a new international legally binding instrument for the conservation and sustainable use of marine biodiversity of ABNJ offers an opportunity to develop new institutions and arrangement. One of the elements under negotiation is the development of a mechanism to implement Area-based Management Tools (ABMTs), including marine protected areas (MPA)s. The negotiations represent a unique opportunity to ensure that the spatial and temporal characteristics of ABMTs are coherent and well aligned with the spatial and temporal scales at which the species, habitats, ecosystems, or processes being managed in ABNJ operate. Our aim is to facilitate the conversation by providing (i) a succinct explanation of the temporal variability in ecological and oceanographic patterns in the high seas and (ii) a basis for linking this knowledge to the present phase of the IGC negotiations.

The high seas are home to a wide range of ecological processes and dynamics, from large-scale migrations by hundreds of species $[7,8]$, to low-productivity, highly stable deep-sea benthic ecosystems rich in biodiversity [9]. Therefore, the ABMTs designed for the conservation and sustainable management of BBNJ should fully reflect the spectrum of variability seen in the open ocean and deep sea and may include a combination of static and dynamic measures. For static or even spatially recurrent features, limited-use MPAs may be the best approach to ensure that benthic habitat structures and associated midwater productivity are protected. However, more dynamic features, such as long-lived eddies and productive fronts may require protections that track such ocean conditions $[10,11]$.

Modern ocean management approaches now make it possible to consider applying dynamic approaches to ABMTs. This has been primarily suggested as a response to the impacts of climate change [12] but also reflects the move to dynamic ocean management in a few instances [13]. Such dynamic approaches to ABMTs are relatively untested but represent a potential future for area-based protection. How they will be applied will depend on the temporal scale of the ocean changes. To help decision-makers account for the dynamism of different ecological and oceanographic processes in the design and implementation of high seas spatial management measures, here we focus on the distinct range of temporal scales that we propose are important for increasing the efficiency and responsiveness of future high seas ABMTs. These are based on the timescales of ecological and oceanographic processes that could inform their design and implementation and are unrelated to the ongoing discussion on whether ABMTs should be time-limited, although may help inform efforts to adjust ABMT boundaries under a changing climate.

This paper identifies four temporal scales which apply to ocean ecosystems and discusses how dynamic ABMTs should be designed to reflect processes within these scales. We first enumerate the existing sectoral ABMTs currently in place in the high seas, followed by a series of case studies which explore four temporal scales: contemporary, intraannual, multi-annual and multidecadal, as outlined in Fig. 1. By aligning the choice of ABMT used to the temporal variability in the environment, managers may improve the efficiency and responsiveness of ABMTs to changing environmental conditions and human pressures [14]. The paper then considers the draft negotiating text produced for the fourth IGC originally scheduled for March 2020 (though postponed under UNGA decision 74/543) and makes recommendations as to how the new BBNJ treaty could ensure that it keeps open the options for dynamic ABMTs and thus options for addressing the increasing human stressors on BBNJ.

\section{ABMTs in the high seas: few, static and sectoral}

ABMTs encompass a wide range of management measures which vary across multiple aspects. Tools may be sectoral or cross-sectoral, static or dynamic in space and time, benthic and/or pelagic, as well as feature-specific or applicable to entire regions. Sector-specific ABMTs regulate the distribution, timing and intensity of a specific industry, such as shipping or fishing, while cross-sectoral tools aim to orchestrate the

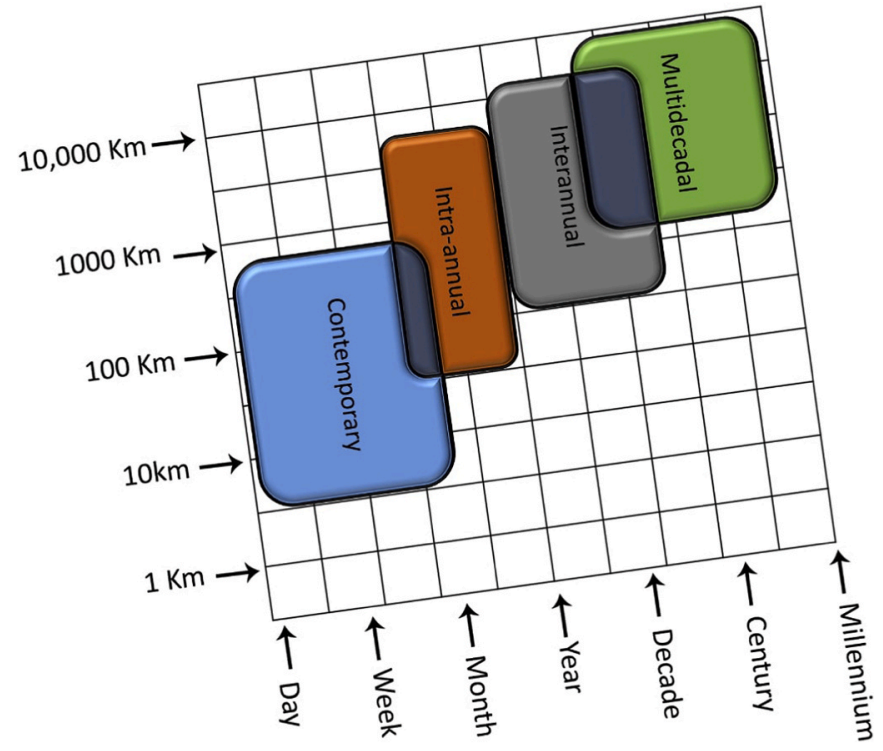

Fig. 1. Stommel diagram depicting the four main spatiotemporal scales of relevance to high seas non-static ABMTs: contemporary, intra-annual, multiannual and multidecadal. Most of the ecological and oceanographic processes that influence the meso- or macro-scale distribution of BBNJ can be categorized by the spatial and temporal scales at which they operate; this categorization may facilitate the process of describing, designing and implementing spatial management measures at those spatial and temporal scales of relevance.

distribution, access and intensity of multiple stressors to mitigate cumulative impacts. Cross-sectoral ABMTs include marine spatial planning, MPAs, integrated coastal zone management and ocean zoning [15].

MPAs have gained momentum as the preferred ABMT to minimize adverse impacts of human activities on coastal marine biodiversity [16], however their implementation in ABNJ and that of any other form of cross-sectoral ABMT has been very restricted. While there is no single institutional organization with the mandate or responsibility to address multi-sectoral issues or to undertake cross-sectoral planning in the high seas, various regional governance bodies have designated MPAs within the areas under their jurisdiction [17]; these regions include the Mediterranean, Northeast Atlantic and the Southern Ocean. The 12 MPAs in these regions (excluding the Mediterranean high seas) collectively cover only $1.18 \%$ of the high seas $[18,19]$. This value is far from the 2020 target of $10 \%$ that the Parties to the CBD [20], and the $16.03 \%$ within EEZs [19]. All existing MPAs in ABNJ are static in space and time, which may limit their utility as species shift their distributions under climate change [21].

Over the 15 years since the UNGA passed a resolution to prevent the significant adverse impacts of bottom fisheries on Vulnerable Marine Ecosystems (VMEs), which are designated by RFMOs to protect deep sea habitats from the impacts of bottom contact fishing gear, five of the eight non-tuna RFMOs that manage bottom fisheries have established approximately 30 VME closures [15] or analogous Fisheries Restricted Area closures. These are complemented by a series of 13 voluntary Benthic Protected Areas established in the south Indian Ocean by the Southern Indian Ocean Fisheries Agreement [22]. RFMOs have made far less progress in the establishment of ABMTs in the pelagic realm, likely due to the complexities of identifying spatially explicit conservation features in a highly fluid and dynamic system like the open-ocean. Spatially-static pelagic ABMTs have been established by three of the five tuna RFMOs: the International Commission for the Conservation of Atlantic Tuna (ICCAT); the Inter-American Tropical Tuna Commission (IATTC) and the Indian Ocean Tuna Commission (IOTC). However, these closures are tailored to certain types of fishing and remain poorly enforced [23]. 
Besides sectoral fishing closures, deep-sea mining is the only other sector to have implemented spatial management measures in ABNJ by adopting a network of nine Areas of Particular Environmental Interest (APEIs) where mining activities are not permitted. These APEIs were established on a provisional basis as part of an Environmental Management Plan for the Clarion Clipperton Zone of the Central Pacific [17]. So far, the International Maritime Organization (IMO) has not identified or established any particularly sensitive sea areas (PSSAs) in the high seas, nor is there any form of spatial zoning or management for the extraction of marine genetic resources, aquaculture, cable laying, oil and gas exploration or the deployment of renewable energy infrastructure. The effectiveness of sectoral closures, such as VMEs, will likely be compromised by the impacts of climate change [21].

Even when not fully dynamic, pelagic protected areas that adjust seasonally or even inter-annually have a greater ability to protect highly-migratory species as they move through the ecosystem responding to interannual variability [24]. As the IGC negotiates the terms for a new treaty which will lead to the next generation of high seas ABMTs, a key consideration will be to ensure such ABMTs are capable of responding to changes in the varying spatiotemporal dynamics of the species, ecosystem or feature they are designed to protect in the present and into the future.

\section{Spatial management across four temporal scales}

Differences in scale and the lack of historical predictability of patterns and processes in oceanic systems have hindered the development and implementation of dynamic or forecast-based spatial management measures [25]. In addition, the absence of legal mandates calling for and enabling the dynamic management of ocean resources has further hindered use of dynamic ABMTs [26], resulting in most spatial management measures across sectors being static in space and time. This can be an issue as the ocean is an ever-changing system, with variability increasing due to the ongoing impacts of climate change. While the concept and some of the most innovative models of dynamic spatial management of marine resources were developed over a decade ago [10, $27,28]$, progress on implementing these tools has been slow. Regardless, dynamic ocean management measures have been proven to increase the efficiency with which area-based marine fisheries management can meet desired objectives (e.g., reduction of finfish bycatch; [14]), and have been applied to both demersal [29] and pelagic systems [24,27,28]. In spite of the increased interest in dynamic management of ocean resources and activities over the last two decades and the growing evidence of the effectiveness of these tools, no international sectoral bodies have called for the use of more spatiotemporally efficient ABMTs even though they may be both possible and feasible. Ensuring that the temporal scales of variability in high seas ecosystems and human stressors are considered in the ABMTs conversation can ensure that the next generation of spatial management measures in the high seas will be more capable of responding to a changing ocean across temporal scales.

Adopting the appropriate temporal scales of management requires understanding the distributional dynamics of both the species or ecosystem of interest and the stressors which may interact with it. Here we describe the four most relevant cyclic and non-cyclic timescales for designing high seas ABMTs: contemporary, intra-annual, multiannual, and multidecadal.

\subsection{Contemporary: dynamic and ephemeral oceanographic features}

Resources in marine systems are often patchily distributed [30], resulting in ephemeral aggregations of prey and predators at productive ocean features [31]. Pelagic biodiversity patterns have been linked to mesoscale features including eddies, jets, upwelling shadows, and fronts all of which can result when currents meander, water masses meet, or nutrient rich waters interact with bathymetric or orographic relief [32-34]. In turn, there can be increased catch rates of non-target species when fishing at these features $[35,36]$. Such features can vary in temporal scale from hour-long tidally driven hotspots [37,38] and diel vertical migration [39], to features persisting for months in the case of large eddies, e.g. Fig. 2 [40,41], or even permanently for some seamounts.

Dynamic ocean management (DOM) is a management approach that uses high spatiotemporal resolution environmental and biological data to enable rapid and optimal management responses to changing distributions of biological resources [11,42,43]. Efficiency here means greater access to ecosystem services while minimizing risk, for example the reduction of non-target species bycatch without a reduction of target catch [14]. Similar approaches have been aimed at reducing ship-strike risks highlighting the multi-sectoral opportunities beyond fisheries [44, 45]. Satellite-based remote sensing and tracking technologies ensures that DOM can be enforced and appropriately matched to these relatively near-term timescales $[5,46]$.

DOM can be useful in two specific modes: responsive and forecasting. The responsive mode of DOM approaches evaluate and respond to fine resolution spatiotemporal changes. In this mode, DOM has been able to better identify, track and target dynamic and ephemeral features [46]. In the forecasting mode, DOM can be used to assess the skill of feature predictability and the likelihood of a biological response to better identify new opportunities for implementing dynamic predictive approaches to spatial management. For example, recurrent processes where hotspot formation can be predicted and protected based on tidal stage, time of day, seasonal processes or bathymetry may offer the greatest opportunity for operationalizing near-term forecasts [31,42]. This approach could be used to not only reduce the adverse direct impacts of various sectoral activities (such as bycatch), but also increase the efficiency of sectors such as fisheries by forecasting areas of high target productivity [47].

\subsection{Intra-annual: seasonal variation}

The intra-annual timescale encompasses monthly to seasonal variation. Climatic conditions strongly influence the abiotic factors that regulate the biological cycle of primary producers, and, by extension, the timing, intensity and duration of their blooming period [48]. Seasonal oscillations of marine primary producers are crucial for open ocean marine ecosystems as they represent the only fresh input of organic matter and hence drive most of biotic biomass change in marine trophic webs. The wealth of knowledge and predictive capacity surrounding intra-annual patterns of variability of ecological and oceanographic processes may facilitate the implementation of more high seas ABMTs that respond to changes at this temporal scale by the relevant management bodies.

The distributions and compositions of open-ocean biological communities are largely governed by predictable intra-annual cyclical processes that influence the life histories of marine biota. These patterns of intra-annual biophysical change are well studied, and, in the case of temperature have been mapped climatologically across multiple depths, as shown in Fig. 3. There are two principal mechanisms controlling the intra-annual spatiotemporal distribution of high seas biodiversity: (i) changes induced by changes in the suitability of the surrounding environment, both biotic (e.g. prey field) and abiotic (e.g. thermal environment) and (ii) behaviorally ingrained movement patterns (e.g. migration) that are loosely associated with immediate environmental preferences.

These cyclic (thus predictable) changes in the abundance of primary and secondary producers are important drivers of distribution of species in higher trophic levels. An example of an oceanic system that experiences significant seasonal changes in its oceanographic and ecological characteristics is the Costa Rica thermal dome (CRTD). The CRTD is a hotspot of oceanic biodiversity that expands and contracts in all three spatial dimensions throughout the year. The thermocline ('dome') of the CRTD shoals between the months of July and November compressing 


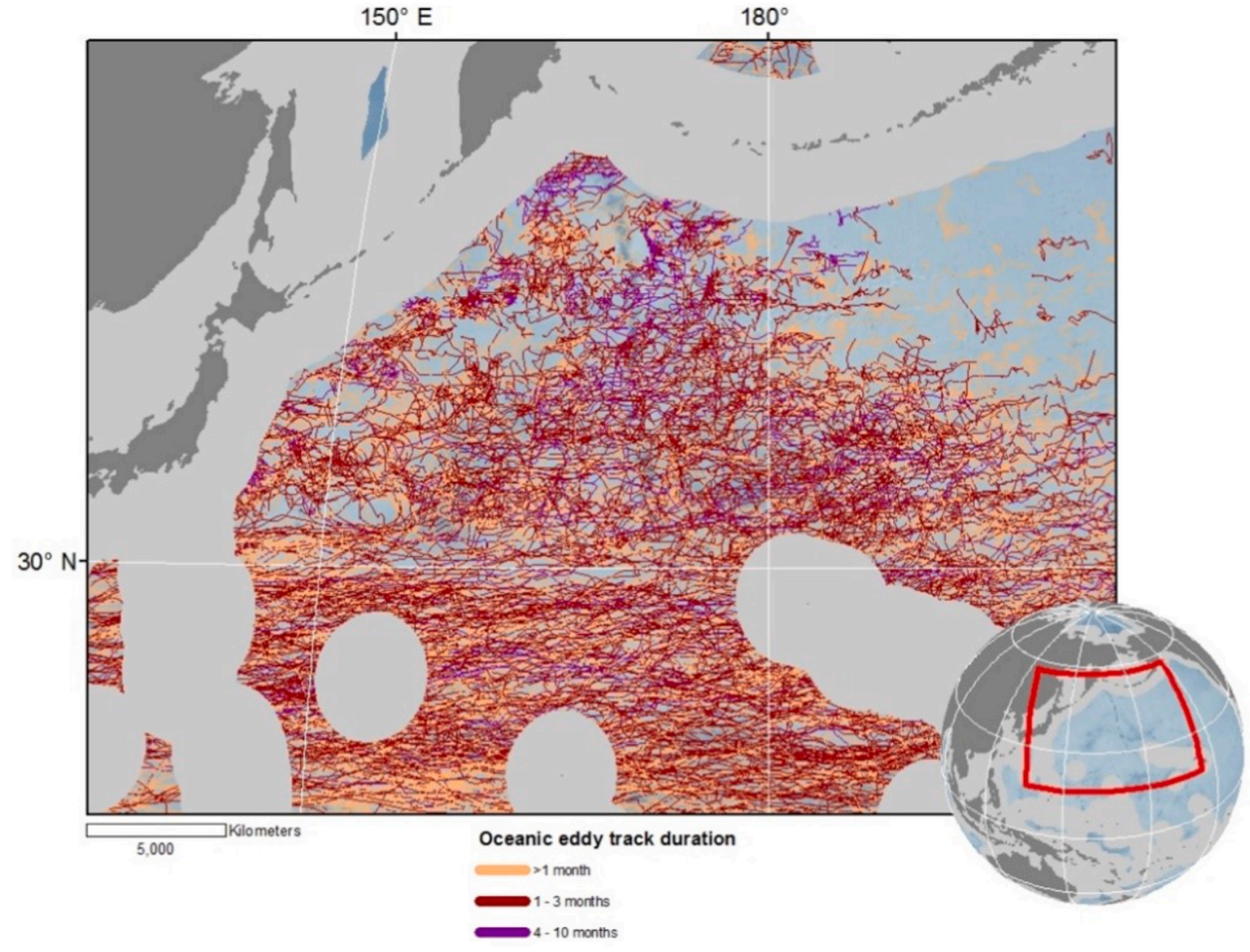

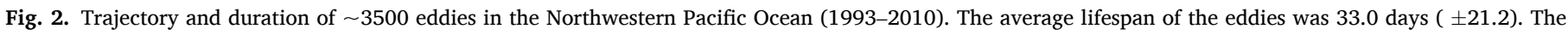
average length of the eddy trajectories was $872.1 \mathrm{Km}$ ( \pm 697.3$)$, resulting in average speeds of $26.4 \mathrm{Km}$ per day.

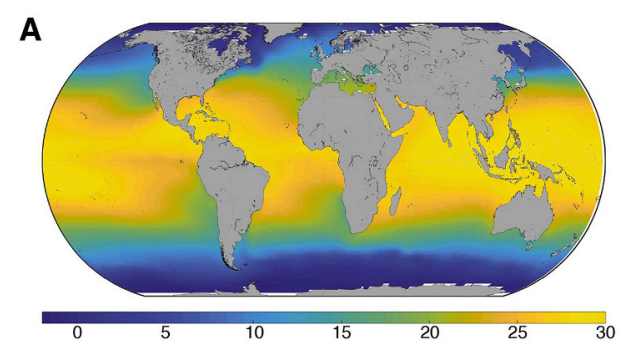

C

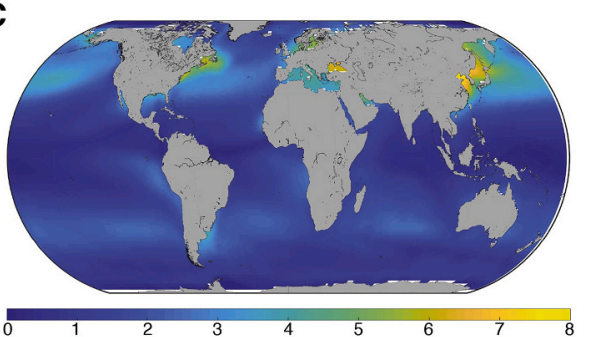

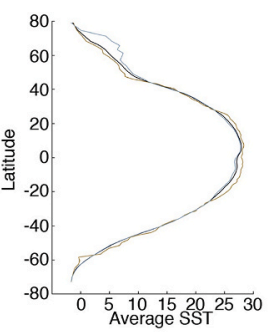
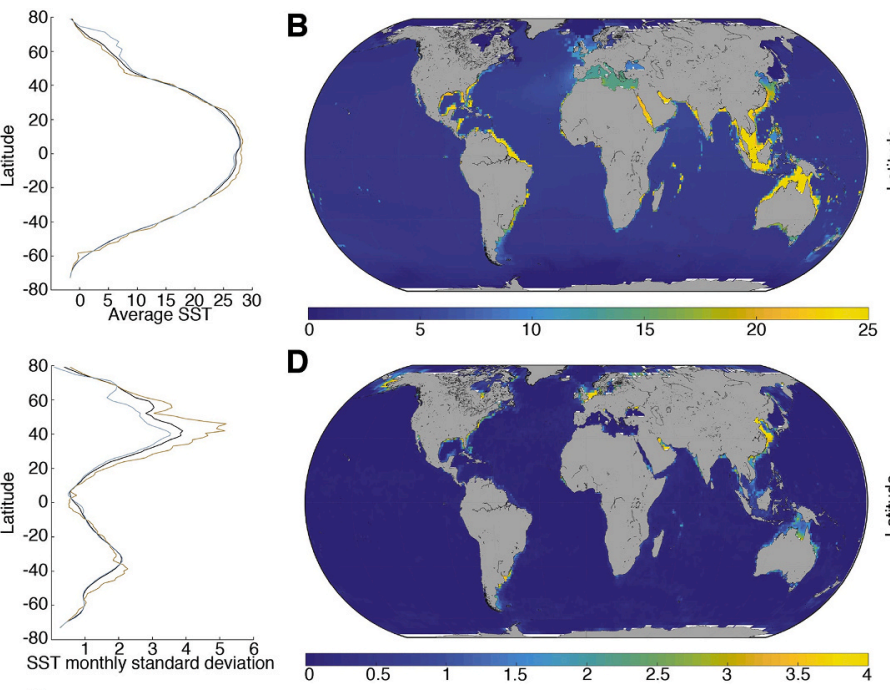
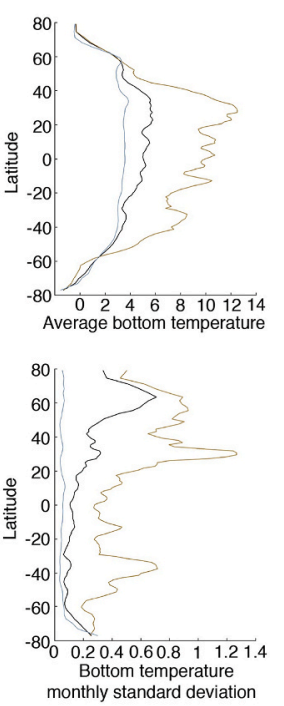

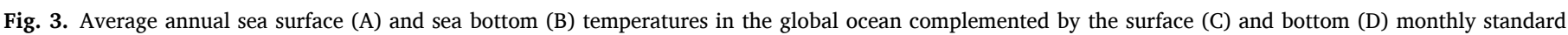

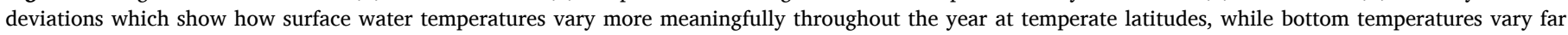
less noticeably.

the vertical habitat available to oceanic species, as well as increasing the productivity in the region due to upwelling [49]. This seasonal primary productivity pump supports a rich community of surface predators, including marine mammals, seabirds, tuna and sharks [49].

These seasonal cycles in food supply also dictate the timing of long- distance migrations of marine species [50] such as Sooty shearwaters (Puffinus griseus), which perform one of the longest migrations in the ocean, from breeding colonies in the southern hemisphere to wintering ground in the northern hemisphere [51]. Like most of the of the $>800$ marine migratory vertebrates (fish, marine reptiles, marine mammals 
and seabirds; [8]), this seasonal journey exposes Sooty shearwaters to a myriad of environmental conditions and anthropogenic stressors which can be reliably mapped over space and time. Our growing understanding of these migratory behaviors [52-54] and aggregation of that knowledge (e.g., through the Migratory Connectivity in the Ocean (MiCO) System [23]) is allowing for improvements on their dynamic spatiotemporal management [28]. While none of the spatiotemporal closures to fishing that RFMOs have established in ABNJ are aimed for the conservation of pelagic biodiversity (with the exception of CCAMLR), they are good examples of seasonal pelagic closures that mitigate negative fisheries impacts. Seasonal ABMTs can be informed and improved through analyses and projections of the spatial behaviors of seasonal human activities at this temporal scale, such as commercial fishing [55]. Such models could improve our ability to predict and isolate activities from areas of high risk, to identify the most appropriate times of the year to establish monthly or seasonal closures to activities that are likely to dynamically overlap with non-target biodiversity, such as fishing, maritime traffic and shipping.

\subsection{Multi-annual: climatic oscillations}

A wide series of coupled ocean-atmospheric climate patterns exert large control over physical and biological processes in every ocean basin, see Table 1 . Our understanding of the underlying forces driving the variability and impacts of these cycles is highly patchy, however, we know that these oscillations not only change the physical properties of the ocean, including the intensity and direction of ocean currents, but also restructure entire biological communities by modifying the intensity and location of bottom-up productivity [56]. Such is the impact of the switching in mode of some of these phenomena (e.g. the Pacific

\section{Table 1}

The periodicity, distribution and characteristics of the main climatic oscillations in the global ocean. These primarily affect pressure and temperature regimes.

\begin{tabular}{|c|c|c|c|c|}
\hline $\begin{array}{l}\text { Climatic } \\
\text { pattern }\end{array}$ & Acronym & Periodicity & $\begin{array}{l}\text { Ocean } \\
\text { region(s) }\end{array}$ & Characteristics \\
\hline $\begin{array}{l}\text { Atlantic } \\
\text { Multidecadal } \\
\text { Oscillation }\end{array}$ & AMO & $\begin{array}{l}\text { Quasi- } \\
\text { periodic }(\sim 70 \\
\text { years })\end{array}$ & $\begin{array}{l}\text { North } \\
\text { Atlantic } \\
\text { Ocean }\end{array}$ & $\begin{array}{l}\text { Changes in sea } \\
\text { surface } \\
\text { temperature }\end{array}$ \\
\hline $\begin{array}{l}\text { Arctic } \\
\text { Oscillation }\end{array}$ & $\mathrm{AO}$ & $\begin{array}{l}\text { No } \\
\text { periodicity }\end{array}$ & $\begin{array}{l}\text { North of } \\
20 \mathrm{~N}\end{array}$ & $\begin{array}{l}\text { Sea-level pressure } \\
\text { variations }\end{array}$ \\
\hline $\begin{array}{l}\text { El Niño- } \\
\text { Southern } \\
\text { Oscillation }\end{array}$ & ENSO & $\begin{array}{l}\text { Quasi- } \\
\text { periodic }(\sim 5 \\
\text { years })\end{array}$ & $\begin{array}{l}\text { Pacific } \\
\text { Ocean }\end{array}$ & $\begin{array}{l}\text { Warm and cold } \\
\text { phases: changes in } \\
\text { air surface pressure } \\
\text { and temperature. }\end{array}$ \\
\hline $\begin{array}{l}\text { Indian Ocean } \\
\text { Dipole }\end{array}$ & IOD & $\begin{array}{l}\text { Quasi- } \\
\text { periodic (may } \\
\text { change under } \\
\text { climate } \\
\text { change) }\end{array}$ & $\begin{array}{l}\text { Indian } \\
\text { Ocean }\end{array}$ & $\begin{array}{l}\text { Irregular } \\
\text { oscillations of sea } \\
\text { surface } \\
\text { temperature. }\end{array}$ \\
\hline $\begin{array}{l}\text { Interdecadal } \\
\text { Pacific } \\
\text { Oscillation }\end{array}$ & IPO & $\begin{array}{l}\text { Quasi- } \\
\text { periodic } \\
\text { (15-30 years) }\end{array}$ & $\begin{array}{l}\text { North and } \\
\text { South } \\
\text { Pacific } \\
\text { Ocean }\end{array}$ & $\begin{array}{l}\text { Sea surface } \\
\text { temperature and } \\
\text { sea-level pressure. }\end{array}$ \\
\hline $\begin{array}{l}\text { North Atlantic } \\
\text { Oscillation }\end{array}$ & NAO & $\begin{array}{l}\text { No } \\
\text { Periodicity }\end{array}$ & $\begin{array}{l}\text { North } \\
\text { Atlantic } \\
\text { Ocean }\end{array}$ & $\begin{array}{l}\text { Changes in air } \\
\text { pressure and } \\
\text { temperature }\end{array}$ \\
\hline $\begin{array}{l}\text { Pacific Decadal } \\
\text { Oscillation }\end{array}$ & PDO & $\begin{array}{l}\text { Inter-decadal } \\
\text { shifts (20-30 } \\
\text { years) }\end{array}$ & $\begin{array}{l}\text { Pacific } \\
\text { Ocean }\end{array}$ & Ocean temperature \\
\hline $\begin{array}{l}\text { Quasi-biennial } \\
\text { Oscillation }\end{array}$ & QBO & $\begin{array}{l}\text { Quasi- } \\
\text { periodic } \\
(28-29 \\
\text { months })\end{array}$ & $\begin{array}{l}\text { Tropical } \\
\text { latitudes }\end{array}$ & $\begin{array}{l}\text { Disruption in } \\
\text { tropical wind } \\
\text { patterns }\end{array}$ \\
\hline $\begin{array}{l}\text { Quasi-decadal } \\
\text { Oscillation }\end{array}$ & QDO & $\begin{array}{l}\text { Quasi- } \\
\text { periodic } \\
\text { (8-12 years) }\end{array}$ & $\begin{array}{l}\text { Tropical } \\
\text { Pacific } \\
\text { Ocean }\end{array}$ & $\begin{array}{l}\text { Sea surface } \\
\text { temperature } \\
\text { anomalies }\end{array}$ \\
\hline $\begin{array}{l}\text { Southern } \\
\text { Annular } \\
\text { mode }\end{array}$ & SAM & $\begin{array}{l}\text { Quasi- } \\
\text { periodic (not } \\
\text { specified) }\end{array}$ & $\begin{array}{l}\text { Southern } \\
\text { Ocean }\end{array}$ & $\begin{array}{l}\text { Changes in ice } \\
\text { coverage, } \\
\text { temperature and } \\
\text { winds }\end{array}$ \\
\hline
\end{tabular}

Decadal Oscillation (PDO), that the term "regime shift" was coined to describe the changes in climatic and biological conditions that persist [57]. These climatic changes have profound effects on regional primary and secondary productivity, distribution [58] and catch [59] of fisheries resources and current, oxygen and temperature regimes, e.g., Fig. 4 [60].

Climate variability in recent years has included incidences of reduced mixing resulting in marine heatwaves that have lasting ecosystem effects $[47,48]$. These oceanic extremes result in broad-scale distributional changes of marine species, in some cases by blocking access to habitat, not only for planktonic species [61], but also nektonic species as is the case of juvenile turtles migrating across the Pacific, or allowing access to species such as the Humboldt squid, which have invaded the northern California current [62]. Some of these climatic patterns follow predictable cycles, however, others may follow quasi-periodic patterns or have no periodicity at all; this makes the latter two hard to predict. Despite these unknowns, we are gaining a better understanding of the biological and ecological ramifications of many of these patterns and oscillations. Since these changes can also disrupt the migratory pathways of pelagic predators [62], it is possible for these events to spatially reconfigure pelagic communities in new ways that predictive models under average environmental conditions fail to capture; thus, arguing that a future governance structure for ABNJ allows for adaptive and dynamic ABMTs that can capture and respond to changes in oceanographic conditions across multiple spatiotemporal scales.

As species distributions shift with annual cycles, traditional policy approaches are often slow to adapt, resulting in high risk and often an insufficient response [63]. Intra-annual and permanent closures are often targeted to average conditions with seasonal closures addressing the time-period of most concern [47,64]. As such, protected areas are often located in the most historically productive areas while accounting for socio-ecological needs $[65,66]$. This approach largely succeeds during average conditions, but anomalous conditions such as marine heatwaves or other climatic oscillations can reconfigure the overlap between managed species and threats, as is the case of foraging humpback whales and crab fisheries in the California Current [67]. There is a need to account for the extremes to ensure that anomalous years do not result in irreparable damage to recovering or protected populations (e.g. right whales) $[63,68]$. Long distance connectivity through oceanographic larval transport can also be directly affected by climatic oscillations, with surface currents only connecting distant habitats during some phases of an oscillation and not others [61]. These extreme conditions can be detected contemporaneously and addressed through dynamic ABMTs that are in place as long as the oceanographic conditions last. Again, this is only feasible if a governance structure is in place to allow for the implementation of dynamic ABMTs.

\subsection{Multidecadal: climate change}

Climate change is impacting and will continue to impact marine biological resources through effects on factors such as species distributions [69,70], thermal stress [71], metabolic and competitive interactions [72], body size [73], and other background impacts such as ocean acidification and increase in hypoxic areas [74].

Marine biological resources are already redistributing in the face of climate change, and this process will accelerate over the coming century. While there is extensive evidence that much of the redistribution of marine biodiversity is pole-ward movement [70,75], Pinsky et al. (2013) suggest that climate velocities will play an important role in determining the distribution and pace of relocation of marine biota, leading to a wide range of shifts; including longitudinal displacements or movements towards the equator. Changes in the vertical dimension are less well studied, but may be driven by oxygen availability as well as thermal stress which is known to influence the vertical distribution of pelagic [76] and benthic species. Shifts in the vertical distribution of pelagic 


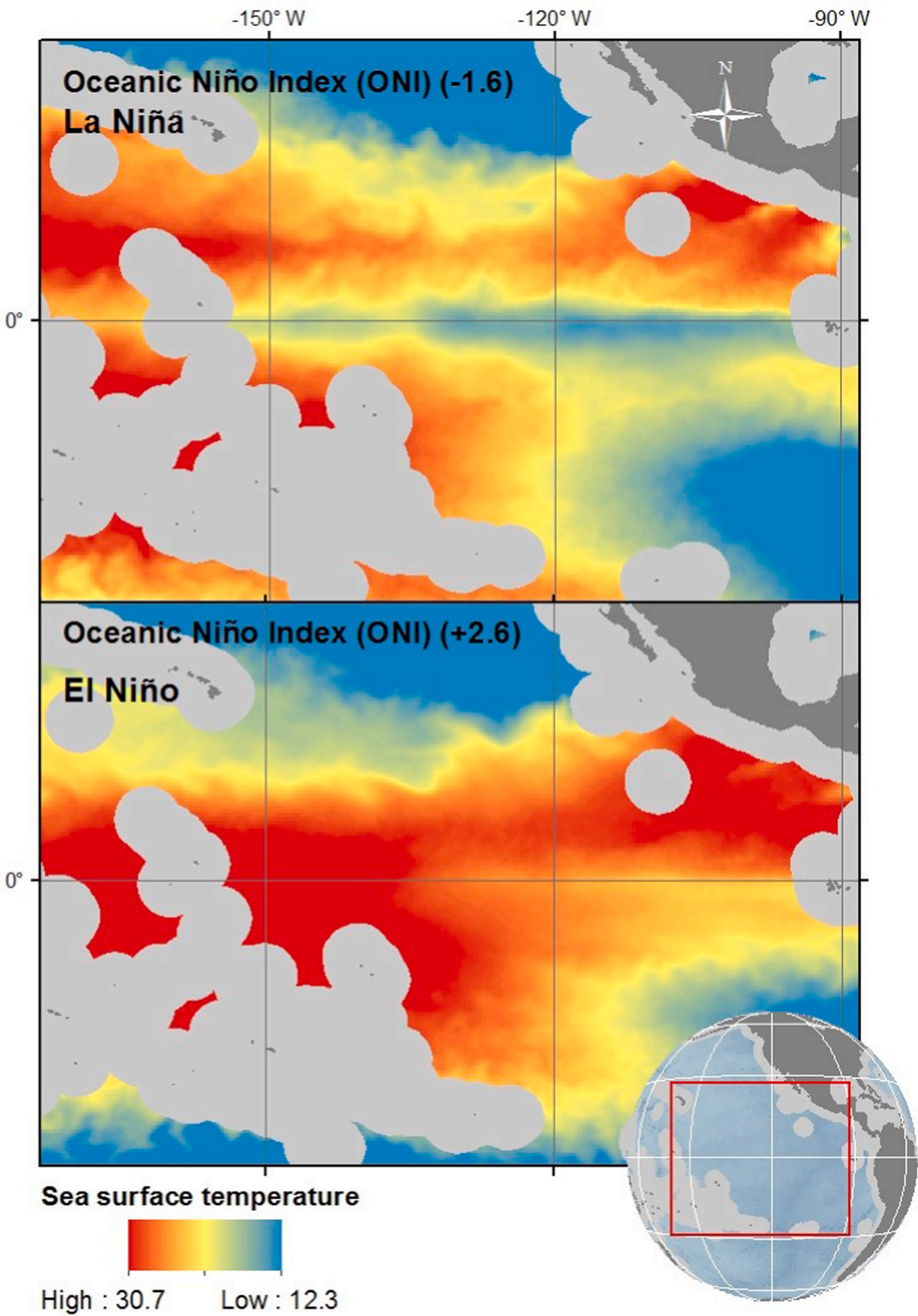

Fig. 4. Differences in November sea surface temperature under a 2010 La Niña (top) and a 2016 El Niño (bottom). 
species due to climate change may also impact their vulnerability to fisheries interactions; there is already evidence of differentiated vulnerabilities of oceanic species to fishing gear across depths [77].

In addition to shifts in distribution, the size of core habitat areas may shift under climate change, as predicted by Hazen et al. (2013), which estimated up to a $35 \%$ change in the core habitat area of predatory species accompanying a poleward shift in distribution. Further important migratory habitats such as the North Pacific Transition Zone were predicted to lose their importance as ocean waters warm which may serve as a barrier for east-west migration across the Pacific or may result in more diffuse patterns [31]. Static regulations under a changing climate may limit the ability for fisheries and other resource users to adapt to changing ocean conditions particularly where species cross jurisdictional boundaries, unless said measures are revised under changing climatic conditions [78,79].

On climate-change timescales, a key question then becomes whether the present or future MPA network becomes more or less effective due to the redistribution and changed vulnerability of species; some evidence already suggests reduced effectiveness [21]. MPAs which are specifically targeted to address the preservation of a specific species or habitat (e.g. seagrass) are likely to be impacted in terms of their ability to meet stated targets if such resources will relocate or face additional threats. Predictive models of species distributions are able to help the ability to assess the likelihood of this happening.

Multiple management tools can be deployed to help integrate climate resilience into MPA networks [12]. A combination of static and dynamic tools at multiple scales can be used to build corridors and stepping-stones to enable climate-driven migration [12]. Having the ability to both assess and adapt protections can allow more pro-active response to shifting conditions, however this also may limit their permanence under changing governance regimes [74]. Thus, governance structures need to enable both static and dynamic approaches to ABMTs, while also embracing the principle of non-regression which prohibits any recession of environmental law or existing levels of environmental protection.

\section{Dynamic governance in the BBNJ treaty across temporal scales}

The advancement in scientific tools and understanding of the oceans processes and dynamics offer opportunities to better govern the ABNJ over differing timescales and spatial extents. In the future, ABMTs in ABNJ may be adaptable to respond to dynamic ocean conditions and even the impacts of climate change [80]. Of course, dynamic management or adaptable tools will not be appropriate in all cases, and will depend on the specific location and management challenge [28,81]. However, even relatively stable ABMTs may need a mechanism to periodically review their boundaries and measures over time to enable boundaries to be adjusted when appropriate.

It may currently be possible for some bodies to implement ABMTs capable of adapting to changing oceanographic or ecological conditions (i.e. flexible ABMTs) in ABNJ, assuming sufficient political will and scientific and technical capability. Indeed, as already mentioned, some RFMOs use conservation and management measures that have a temporal element. However, there may be a question in some global, regional or sectoral bodies, whether there is a legal competence to create more advanced flexible ABMTs. Thus, it is important for the new instrument to provide a legal platform that specifically enables, rather than inhibits or ignores, the implementation and monitoring of dynamic tools in ABNJ.

The current draft text for the BBNJ ILBI narrowly defines the term ABMT as a tool for a "geographically defined area" (Article 1.3). This limited definition could be expanded to more explicitly account for the temporally dynamic and flexible management approaches described in this paper. Our ability to define ABMTs in both space and time is a fundamental attribute of this more dynamic approach under a changing ocean. Thus, ABMTs could be defined as "spatially explicit management measures for which there is a clear definition of the ecological and temporal scales of action to achieve one or more objectives of the instrument'. Such a definition would enable novel approaches including, inter alia, dynamic MPAs [13] and climate-responsive biodiversity closures [12].

To 'future-proof' the new instrument, we recommend the development of an effective legal framework that will allow for ABMTs well into the future, including through integrated planning and management of ABMTs across sectors and regions. This will require a set of obligations and institutional frameworks that promotes cooperation between existing global, regional and sectoral bodies to implement good practice in area-based management. Three elements will be key. First, general obligations that clearly mandate States Parties to progress ABMTs for biodiversity conservation and management in all relevant bodies to which they are members. Second, institutional arrangements under the new instrument should have the ability to further develop the law and processes relevant to ABMTs in ABNJ as necessary. Third, specific provisions in the instrument could ensure that ABMTs are not limited to static entities (e.g. most existing MPAs) yet could be made up of a patchwork of dynamic to static protections or modes. Inclusion of these elements, many of which are not novel in themselves, in the ABMT provisions will ensure that measures under the ILBI will be more effective in the long term.

\section{General obligations and principles}

A starting point would be that the ILBI contains an obligation on States to cooperate to establish ABMTs, including MPAs, to protect and conserve marine biodiversity and to ensure that uses of the components of biodiversity are sustainable. This obligation could be further developed through objectives, criteria and guidelines set forth in the ILBI as Annexes or subsequently by a Conference of Parties (COP). Such provisions could be modelled on articles $5,6,7,8$ and 10 of the CBD, or article II of the Convention on Migratory Species (CMS). Other general principles that would support and enhance flexible ABMTs include applying the precautionary approach, adaptive management, ecosystem-based management and using best-available science and technologies as per article 5 of the UN Fish Stocks Agreement. Incorporating these principles into the ILBI would not, in themselves, achieve flexible ABMTs. However, they would form a framework of legal principles that can inform and guide the application of ABMTs to ensure that the management response is environmentally appropriate. Their presence in the ILBI may also encourage their uptake in other instruments and bodies and provide a basis to review and assess progress.

\section{Institutional arrangements}

States are still debating the options for how ABMTs in ABNJ will be established, monitored and reviewed. Assuming that the ILBI contains provisions on these aspects, it would be useful to include the following. First, ABMTs should be established with clear management and conservation objectives that guide the design of the tool. These are also important for potential revision of the ABMT, including its physical, ecological and temporal scopes. Where flexible ABMTs are considered appropriate, the design could ensure that active monitoring, review, and adaptability is built into the process.

Where possible, a process that facilitates cross-sectoral ABMTs should retain the ability to implement flexibility into the design, since human uses of marine spaces change dynamically. Such facilitation could be through the Conference of Parties (COP) playing a coordinating role among global, regional and sectoral bodies, or the ILBI could establish a regime that has a more active role for the COP or other body in designing, implementing and monitoring the ABMTs. 


\section{Specific provisions on ABMTs}

We recommend that ABMTs be flexible so that, if necessary or desirable, their geographic boundaries can change over time. ABMTs should be able to be defined so that the management and conservation goals could include dynamic or non-static aspects. For example, it could be acknowledged that the geographic boundaries may need to shift over time due to external threats such as climate change, but also that the measures may change at different times of the year. For certainty, it will be necessary to ensure that the area in which the ABMT is operating is clear to all States, but these areas could themselves be dynamic, thus requiring the establishment of appropriate mechanisms (e.g. online portals) to update and inform all relevant stakeholders.

ABMTs should be regularly reviewed in light of their objectives. This is where adaptive management can assist in ensuring that information is gathered about the implementation of the ABMT and the status of the ecosystems, which can be used to determine whether adjustments need to be made to the boundaries, but also the conservation and management measures. While the design and implementation of adaptive spatial management tools is not novel in the field of marine conservation and management, there are virtually no examples successfully implemented adaptive spatial management closures in ABNJ. Once these are implemented, it will be important to provide that any revision of the boundaries of an MPA or other ABMT should not weaken the strength of the provisions in achieving the objectives of the measure as there is a political risk of subsequent attempts to claw back the levels of protection [82]. Alternatively, any revision of boundaries should lead to an outcome that is at least as effective at achieving the stated objectives as the previous version. Reviewing the spatiotemporal boundaries of an ABMT is an opportunity to increase the efficiency of the tool and should not be used to weaken its impact.

The ILBI should provide for compliance and monitoring. This could include obligations to collect and share data about activities in the area of the ABMT (as per Art. 5 (j) of the UN Fish Stocks Agreement) and arrangements for monitoring control and surveillance to ensure adherence to conservation and management measures by vessels in the area. A new ILBI could request all States operating in ABNJ to report the location of their activities via AIS or VMS technologies.

\section{Conclusion}

Almost 40 years after the creation of the UNCLOS, we have a second opportunity as a global community to better address the conservation of living resources, and the study, protection and preservation of the marine environment beyond national boundaries, as envisaged in the Preamble of UNCLOS. Human activities in ABNJ and our understanding of their impacts on BBNJ are far more advanced than they were when UNCLOS was drafted. In the context of ABMTs, we now have evidence of the importance of appropriately matching both the spatial and temporal scales of any given ABMT to those of the species, process or ecosystem that it was intended to protect, a process of alignment that the ILBI should reflect. This will require the definition of ABMTs to be expanded to more explicitly account for the temporally dynamic and flexible management approaches described in this paper. While complex, incorporating dynamism to ABMTs in ABNJ is not only logistically and scientifically sound, but may also improve the efficiency of sectors such as fisheries and ensure that the ABMTs that are established under a new treaty can respond to the fast-changing conditions of the global ocean.

\section{Acknowledgements}

We would like to recognize the support provided by the Nippon Foundation Nereus Program for the development of this study. We would also like to thank C. R. Payne for her perspectives on the topic discussed in this manuscript. The scientific results and conclusions, as well as any views or opinions expressed herein, are those of the author(s) and do not necessarily reflect the views of the NOAA or the Department of Commerce.

\section{Appendix A. Supplementary data}

Supplementary data to this article can be found online at https://doi. org/10.1016/j.marpol.2020.104102.

\section{References}

[1] C.C. O'Hara, J.C. Villaseñor-Derbez, G.M. Ralph, B.S. Halpern, Mapping status and conservation of global at-risk marine biodiversity, Conserv. Lett. (2019), e12651.

[2] N. Matz-Lück, J. Fuchs, The impact of OSPAR on protected area management beyond national jurisdiction: effective regional cooperation or a network of paper parks? Mar. Pol. 49 (2014) 155-166.

[3] A. Merrie, D.C. Dunn, M. Metian, A.M. Boustany, Y. Takei, A.O. Elferink, Y. Ota, V. Christensen, P.N. Halpin, H. Österblom, An ocean of surprises-Trends in human use, unexpected dynamics and governance challenges in areas beyond national jurisdiction, Global Environ. Change 27 (2014) 19-31.

[4] N.C. Ban, S.M. Maxwell, D.C. Dunn, A.J. Hobday, N.J. Bax, J. Ardron, K.M. Gjerde, E.T. Game, R. Devillers, D.M. Kaplan, others, Better integration of sectoral planning and management approaches for the interlinked ecology of the open oceans, Mar. Pol. 49 (2014) 127-136.

[5] D.C. Dunn, C. Jablonicky, G.O. Crespo, D.J. McCauley, D.A. Kroodsma, K. Boerder, K.M. Gjerde, P.N. Halpin, Empowering High Seas Governance with Satellite Vessel Tracking Data, Fish Fish, 2018.

[6] K.M. Gjerde, D. Currie, K. Wowk, K. Sack, Ocean in peril: reforming the management of global ocean living resources in areas beyond national jurisdiction, Mar. Pollut. Bull. 74 (2013) 540-551.

[7] S. Fowler, The Conservation Status of Migratory Sharks, UNEPCMS Secr. Bonn Ger., 2014.

[8] B. Lascelles, G. Notarbartolo Di Sciara, T. Agardy, A. Cuttelod, S. Eckert, L. Glowka, E. Hoyt, F. Llewellyn, M. Louzao, V. Ridoux, others, Migratory marine species: their status, threats and conservation management needs, Aquat. Conserv. Mar. Freshw. Ecosyst. 24 (2014) 111-127.

[9] T. Morato, S.D. Hoyle, V. Allain, S.J. Nicol, Seamounts are hotspots of pelagic biodiversity in the open ocean, Proc. Natl. Acad. Sci. 107 (2010) 9707-9711.

[10] K.D. Hyrenbach, K.A. Forney, P.K. Dayton, Marine protected areas and ocean basin management, Aquat. Conserv. Mar. Freshw. Ecosyst. 10 (2000) 437-458.

[11] S.M. Maxwell, E.L. Hazen, R.L. Lewison, D.C. Dunn, H. Bailey, S.J. Bograd, D. K. Briscoe, S. Fossette, A.J. Hobday, M. Bennett, others, Dynamic ocean management: defining and conceptualizing real-time management of the ocean, Mar. Pol. 58 (2015) 42-50.

[12] D.P. Tittensor, M. Beger, K. Boerder, D.G. Boyce, R.D. Cavanagh, A. Cosandey Godin, G.O. Crespo, D.C. Dunn, W. Ghiffary, S.M. Grant, Integrating climate adaptation and biodiversity conservation in the global ocean, Sci. Adv. 5 (2019), eaay9969.

[13] S.M. Maxwell, K.M. Gjerde, M.G. Conners, L.B. Crowder, Mobile protected areas for biodiversity on the high seas, Science 367 (2020) 252-254.

[14] D.C. Dunn, S.M. Maxwell, A.M. Boustany, P.N. Halpin, Dynamic ocean management increases the efficiency and efficacy of fisheries management, Proc Natl. Acad. Sci. 113 (2016) 668-673.

[15] G. Wright, K.M. Gjerde, D.E. Johnson, A. Finkelstein, M.A. Ferreira, D.C. Dunn, M. R. Chaves, A. Grehan, Marine spatial planning in areas beyond national jurisdiction, Mar. Pol. (2019).

[16] N.J. Gray, Sea change: exploring the international effort to promote marine protected areas, Conserv. Soc. 8 (2010) 331.

[17] K.M. Gjerde, L.L.N. Reeve, H. Harden-Davies, J. Ardron, R. Dolan, C. Durussel, S. Earle, J.A. Jimenez, P. Kalas, D. Laffoley, Protecting Earth's last conservation frontier: scientific, management and legal priorities for MPAs beyond national boundaries, Aquat. Conserv. Mar. Freshw. Ecosyst. 26 (2016) 45-60.

[18] D. Smith, J. Jabour, H. editor, A. Serdy, MPAs in ABNJ: lessons from two high seas regimes, ICES J. Mar. Sci. (2017) fsx189.

[19] UNEP-WCMC and IUCN, 2018. World database on protected areas (WDPA)[version March 2018]. Cambridge, UK: World ConservationMonitoring Centre. Available at: www.protectedplanet.net, (n.d.)

[20] CBD, Decisions adopted by the conference of the parties to the convention on biological diversity at its tenth meeting (decision X/2, annex IV), in: Convention on Biological Diversity Nagoya, Japan, 2010.

[21] D. Johnson, M. Adelaide Ferreira, E. Kenchington, Climate change is likely to severely limit the effectiveness of deep-sea ABMTs in the North Atlantic, Mar. Pol. 87 (2018) 111-122, https://doi.org/10.1016/j.marpol.2017.09.034.

[22] SIODFA, Southern Indian Ocean Deepwater Fisheries Association (SIODFA), Benthic Protected Areas in the Southern Indian Ocean. SIODFA Technical Report XVII 16/01, 2016, p. 40.

[23] D.C. Dunn, A.-L. Harrison, C. Curtice, S. DeLand, B. Donnelly, E. Fujioka, E. Heywood, C.Y. Kot, S. Poulin, M. Whitten, The importance of migratory connectivity for global ocean policy, Proc. Roy. Soc. B 286 (2019) 20191472.

[24] E.L. Hazen, K.L. Scales, S.M. Maxwell, D.K. Briscoe, H. Welch, S.J. Bograd, H. Bailey, S.R. Benson, T. Eguchi, H. Dewar, A dynamic ocean management tool to reduce bycatch and support sustainable fisheries, Sci. Adv. 4 (2018) eaar3001. 
[25] M. Jacox, D. Tommasi, M. Alexander, G. Hervieux, C. Stock, Predicting the evolution of the 2014-16 California Current System marine heatwave from an ensemble of coupled global climate forecasts, Front. Mar. Sci. 6 (2019) 497.

[26] A.J. Hobday, S.M. Maxwell, J. Forgie, J. McDonald, Dynamic ocean management: integrating scientific and technological capacity with law, policy, and management, Stan. Envtl. LJ 33 (2013) 125.

[27] A.J. Hobday, K. Hartmann, Near real-time spatial management based on habitat predictions for a longline bycatch species, Fish. Manag. Ecol. 13 (2006) 365-380.

[28] E.A. Howell, D.R. Kobayashi, D.M. Parker, G.H. Balazs, J.J. Polovina, TurtleWatch: a tool to aid in the bycatch reduction of loggerhead turtles Caretta caretta in the Hawaii-based pelagic longline fishery, Endanger. Species Res. 5 (2008) 267-278.

[29] R. Bjorkland, D.C. Dunn, M. McClure, J. Jannot, M.A. Bellman, M. Gleason, K. Schiffers, Spatiotemporal patterns of rockfish bycatch in US west coast groundfish fisheries: opportunities for reducing incidental catch of depleted species, Can. J. Fish. Aquat. Sci. 72 (2015) 1835-1846.

[30] K.J. Benoit-Bird, B.C. Battaile, S.A. Heppell, B. Hoover, D. Irons, N. Jones, K. J. Kuletz, C.A. Nordstrom, R. Paredes, R.M. Suryan, Prey patch patterns predict habitat use by top marine predators with diverse foraging strategies, PloS One 8 (2013).

[31] E.L. Hazen, S. Jorgensen, R.R. Rykaczewski, S.J. Bograd, D.G. Foley, I.D. Jonsen, S. A. Shaffer, J.P. Dunne, D.P. Costa, L.B. Crowder, others, Predicted habitat shifts of Pacific top predators in a changing climate, Nat. Clim. Change 3 (2013) 234-238.

[32] C.-A. Bost, C. Cotté, F. Bailleul, Y. Cherel, J.-B. Charrassin, C. Guinet, D.G. Ainley, H. Weimerskirch, The importance of oceanographic fronts to marine birds and mammals of the southern oceans, J. Mar. Syst. 78 (2009) 363-376.

[33] P.S. Sabarros, F. Ménard, J.-J. Lévénez, E. Tew-Kai, J.-F. Ternon, Mesoscale eddies influence distribution and aggregation patterns of micronekton in the Mozambique Channel, Mar. Ecol. Prog. Ser. 395 (2009) 101-107.

[34] D.P. Tittensor, C. Mora, W. Jetz, H.K. Lotze, D. Ricard, E.V. Berghe, B. Worm, Global patterns and predictors of marine biodiversity across taxa, Nature 466 (2010) 1098-1101.

[35] N. Queiroz, N.E. Humphries, G. Mucientes, N. Hammerschlag, F.P. Lima, K. L. Scales, P.I. Miller, L.L. Sousa, R. Seabra, D.W. Sims, Ocean-wide tracking of pelagic sharks reveals extent of overlap with longline fishing hotspots, Proc. Natl. Acad. Sci. U.S.A. 113 (2016) 1582-1587, https://doi.org/10.1073/ pnas. 1510090113.

[36] K.L. Scales, E.L. Hazen, M.G. Jacox, F. Castruccio, S.M. Maxwell, R.L. Lewison, S. J. Bograd, Fisheries bycatch risk to marine megafauna is intensified in Lagrangian coherent structures, Proc. Natl. Acad. Sci. 115 (2018) 7362-7367.

[37] C. Cotté, Y. Simard, Formation of dense krill patches under tidal forcing at whale feeding hot spots in the St. Lawrence Estuary, Mar. Ecol. Prog. Ser. 288 (2005) 199-210.

[38] E.L. Hazen, A.S. Friedlaender, M.A. Thompson, C.R. Ware, M.T. Weinrich, P. N. Halpin, D.N. Wiley, Fine-scale prey aggregations and foraging ecology of humpback whales Megaptera novaeangliae, Mar. Ecol. Prog. Ser. 395 (2009) 75-89.

[39] G.C. Hays, A review of the adaptive significance and ecosystem consequences of zooplankton diel vertical migrations, in: Migr. Dispersal Mar. Org, Springer, 2003, pp. $163-170$.

[40] A.C. Hsu, A.M. Boustany, J.J. Roberts, J.-H. Chang, P.N. Halpin, Tuna and swordfish catch in the US northwest Atlantic longline fishery in relation to mesoscale eddies, Fish. Oceanogr. 24 (2015) 508-520.

[41] C. Ladd, Interannual variability of the Gulf of Alaska eddy field, Geophys. Res. Lett. 34 (2007).

[42] A.J. Hobday, J.R. Hartog, Derived ocean features for dynamic ocean management, Oceanography 27 (2014) 134-145.

[43] R. Lewison, A.J. Hobday, S. Maxwell, E. Hazen, J.R. Hartog, D.C. Dunn, D. Briscoe, S. Fossette, C.E. O'keefe, M. Barnes, others, Dynamic ocean management: identifying the critical ingredients of dynamic approaches to ocean resource management, Bioscience 65 (2015) 486-498.

[44] B. Abrahms, H. Welch, S. Brodie, M.G. Jacox, E.A. Becker, S.J. Bograd, L.M. Irvine, D.M. Palacios, B.R. Mate, E.L. Hazen, Dynamic ensemble models to predic distributions and anthropogenic risk exposure for highly mobile species, Divers. Distrib. (2019).

[45] E.L. Hazen, D.M. Palacios, K.A. Forney, E.A. Howell, E. Becker, A.L. Hoover, L. Irvine, M. DeAngelis, S.J. Bograd, B.R. Mate, WhaleWatch: a dynamic management tool for predicting blue whale density in the California Current, J. Appl. Ecol. 54 (2017) 1415-1428.

[46] E. Chassot, S. Bonhommeau, G. Reygondeau, K. Nieto, J.J. Polovina, M. Huret, N. K. Dulvy, H. Demarcq, Satellite remote sensing for an ecosystem approach to fisheries management, ICES J. Mar. Sci. 68 (2011) 651-666.

[47] A.J. Hobday, J.R. Hartog, C.M. Spillman, O. Alves, Seasonal forecasting of tun habitat for dynamic spatial management, Can. J. Fish. Aquat. Sci. 68 (2011) 898-911.

[48] R.R. Nemani, C.D. Keeling, H. Hashimoto, W.M. Jolly, S.C. Piper, C.J. Tucker, R. B. Myneni, S.W. Running, Climate-driven increases in global terrestrial net primary production from 1982 to 1999, Science 300 (2003) 1560-1563.

[49] P.C. Fielder, J.V. Redfern, L.T. Ballance, Oceanography and Cetaceans of the Costa Rica Dome Region, 2017.

[50] H. Dingle, The Biology of Life on the Move, Oxford University Press, New York, NY, 1996.

[51] S.A. Shaffer, Y. Tremblay, H. Weimerskirch, D. Scott, D.R. Thompson, P.M. Sagar, H. Moller, G.A. Taylor, D.G. Foley, B.A. Block, Migratory shearwaters integrate oceanic resources across the Pacific Ocean in an endless summer, Proc. Natl. Acad. Sci. 103 (2006) 12799-12802.
[52] B.A. Block, H. Dewar, S.B. Blackwell, T.D. Williams, E.D. Prince, C.J. Farwell, A. Boustany, S.L.H. Teo, A. Seitz, A. Walli, D. Fudge, Migratory movements, depth preferences, and thermal biology of Atlantic bluefin tuna, Science 293 (2001) 1310-1314, https://doi.org/10.1126/science.1061197.

[53] M.C. James, S.A. Eckert, R.A. Myers, Migratory and reproductive movements of male leatherback turtles (Dermochelys coriacea), Mar. Biol. 147 (2005) 845-853.

[54] J.D. Neilson, J. Loefer, E.D. Prince, F. Royer, B. Calmettes, P. Gaspar, R. Lopez, I. Andrushchenko, Seasonal distributions and migrations of Northwest Atlantic swordfish: inferences from integration of pop-up satellite archival tagging studies, PloS One 9 (2014), e112736.

[55] G.O. Crespo, D.C. Dunn, G. Reygondeau, K. Boerder, B. Worm, W. Cheung, D. P. Tittensor, P.N. Halpin, The environmental niche of the global high seas pelagic longline fleet, Sci. Adv. 4 (2018) eaat3681.

[56] M.H. Taylor, J. Tam, V. Blaskovic, P. Espinoza, R.M. Ballón, C. Wosnitza-Mendo, J. Argüelles, E. Díaz, S. Purca, N. Ochoa, Trophic modeling of the northern Humboldt current ecosystem, Part II: elucidating ecosystem dynamics from 1995 to 2004 with a focus on the impact of ENSO, Prog. Oceanogr. 79 (2008) 366-378.

[57] W.T. Peterson, F.B. Schwing, A new climate regime in northeast Pacific ecosystems, Geophys. Res. Lett. 30 (2003).

[58] R. Faillettaz, G. Beaugrand, E. Goberville, R.R. Kirby, Atlantic Multidecadal Oscillations drive the basin-scale distribution of Atlantic bluefin tuna, Sci. Adv. 5 (2019), eaar6993.

[59] P.S. Kumar, G.N. Pillai, U. Manjusha, El Nino southern oscillation (ENSO) impact on tuna fisheries in Indian Ocean, SpringerPlus 3 (2014) 591.

[60] K. Drinkwater, G. Hunt, P. Lehodey, S. Lluch-Cota, E.J. Murphy, Y. Sakurai, F. Schwing, G. Beaugrand, S. Sundby, Climate forcing on marine ecosystems, Mar. Ecosyst. Global Chang. (2010) 11-39.

[61] E.A. Treml, P.N. Halpin, D.L. Urban, L.F. Pratson, Modeling population connectivity by ocean currents, a graph-theoretic approach for marine conservation, Landsc. Ecol. 23 (2008) 19-36.

[62] D.K. Briscoe, A.J. Hobday, A. Carlisle, K. Scales, J.P. Eveson, H. Arrizabalaga, J. N. Druon, J.-M. Fromentin, Ecological bridges and barriers in pelagic ecosystems, Deep Sea Res. Part II Top. Stud. Oceanogr. 140 (2017) 182-192.

[63] E.L. Meyer-Gutbrod, C.H. Greene, K.T. Davies, Marine species range shifts necessitate advanced policy planning: the case of the North Atlantic right whale, Oceanography 31 (2018) 19-23.

[64] T. Eguchi, S.R. Benson, D.G. Foley, K.A. Forney, Predicting overlap between drift gillnet fishing and leatherback turtle habitat in the California Current Ecosystem, Fish. Oceanogr. 26 (2017) 17-33.

[65] S.D. Gaines, S.E. Lester, K. Grorud-Colvert, C. Costello, R. Pollnac, Evolving science of marine reserves: new developments and emerging research frontiers, Proc. Natl. Acad. Sci. 107 (2010) 18251-18255.

[66] C.J. Klein, A. Chan, L. Kircher, A.J. Cundiff, N. Gardner, Y. Hrovat, A. Scholz, B. E. Kendall, S. Airame, Striking a balance between biodiversity conservation and socioeconomic viability in the design of marine protected areas, Conserv. Biol. 22 (2008) 691-700.

[67] L.M. Cavole, A.M. Demko, R.E. Diner, A. Giddings, I. Koester, C.M. Pagniello, M.L. Paulsen, A. Ramirez-Valdez, S.M. Schwenck, N.K. Yen, Biological impacts of the 2013-2015 warm-water anomaly in the Northeast Pacific: winners, losers, and the future, Oceanography 29 (2016) 273-285.

[68] K.T. Davies, S.W. Brillant, Mass human-caused mortality spurs federal action to protect endangered North Atlantic right whales in Canada, Mar. Pol. 104 (2019) $157-162$.

[69] W.W. Cheung, V.W. Lam, J.L. Sarmiento, K. Kearney, R.E.G. Watson, D. Zeller, D. Pauly, Large-scale redistribution of maximum fisheries catch potential in the global ocean under climate change, Global Change Biol. 16 (2010) 24-35.

[70] W.W. Cheung, V.W. Lam, J.L. Sarmiento, K. Kearney, R. Watson, D. Pauly, Projecting global marine biodiversity impacts under climate change scenarios, Fish Fish. 10 (2009) 235-251.

[71] T.P. Hughes, J.T. Kerry, A.H. Baird, S.R. Connolly, T.J. Chase, A. Dietzel, T. Hill, A. S. Hoey, M.O. Hoogenboom, M. Jacobson, Global warming impairs stock-recruitment dynamics of corals, Nature 568 (2019) 387.

[72] J.M. Grady, B.S. Maitner, A.S. Winter, K. Kaschner, D.P. Tittensor, S. Record, F. A. Smith, A.M. Wilson, A.I. Dell, P.L. Zarnetske, Metabolic asymmetry and the global diversity of marine predators, Science 363 (2019) eaat4220.

[73] W.W. Cheung, J.L. Sarmiento, J. Dunne, T.L. Frölicher, V.W. Lam, M.D. Palomares, R. Watson, D. Pauly, Shrinking of fishes exacerbates impacts of global ocean changes on marine ecosystems, Nat. Clim. Change 3 (2013) 254.

[74] F. Chan, J.A. Barth, J. Lubchenco, A. Kirincich, H. Weeks, W.T. Peterson, B. A. Menge, Emergence of anoxia in the California current large marine ecosystem, Science 319 (2008), 920-920.

[75] J.W. Morley, R.L. Selden, R.J. Latour, T.L. Frölicher, R.J. Seagraves, M.L. Pinsky, Projecting shifts in thermal habitat for 686 species on the North American continental shelf, PloS One 13 (2018), e0196127.

[76] A.Z. Horodysky, S.J. Cooke, J.E. Graves, R.W. Brill, Fisheries conservation on the high seas: linking conservation physiology and fisheries ecology for the management of large pelagic fishes, Conserv. Physiol. 4 (2016) cov059.

[77] A.J. Gallagher, E.S. Orbesen, N. Hammerschlag, J.E. Serafy, Vulnerability of oceanic sharks as pelagic longline bycatch, Global Ecol. Conserv. 1 (2014) 50-59, https://doi.org/10.1016/j.gecco.2014.06.003.

[78] K.E. Mills, A.J. Pershing, C.J. Brown, Y. Chen, F.-S. Chiang, D.S. Holland, S. Lehuta, J.A. Nye, J.C. Sun, A.C. Thomas, Fisheries management in a changing climate: lessons from the 2012 ocean heat wave in the Northwest Atlantic, Oceanography 26 (2013) 191-195. 
[79] M.L. Pinsky, G. Reygondeau, R. Caddell, J. Palacios-Abrantes, J. Spijkers, W. W. Cheung, Preparing ocean governance for species on the move, Science 360 (2018) 1189-1191.

[80] K.K. Holsman, E.L. Hazen, A. Haynie, S. Gourguet, A. Hollowed, S.J. Bograd, J. F. Samhouri, K. Aydin, Towards climate resiliency in fisheries management, ICES J. Mar. Sci. (2019).
[81] A.J. Hobday, J.R. Hartog, T. Timmiss, J. Fielding, Dynamic spatial zoning to manage southern bluefin tuna (Thunnus maccoyii) capture in a multi-species longline fishery, Fish. Oceanogr. 19 (2010) 243-253.

[82] G.C. Quirk, H.R. Harden-Davies, Cooperation, competence and coherence: the role of regional ocean governance in the South West Pacific for the conservation and sustainable use of biodiversity beyond national jurisdiction, Int. J. Mar. Coast. Law 32 (2017) 672-708 